\title{
news from our chapters ${ }^{1}$
}

\section{Central Arizona}

The chapter meeting was held on 21 October at Arizona State University, Tempe, Ariz.; 26 members and guests attended. The meeting was called to order at $7 \mathrm{pm}$ by chapter Co-President Richard Rowe.

The featured speaker, chapter Co-President Harold Bulk, gave a very interesting talk on the causes and effects of wind. Bulk said that the natural air motion is for it to rise in the equatorial region and flow to the polar regions, where it descends and flows back once again to the equator. As the air flows it is deflected (to the right in the Northern Hemisphere) by the rotation of the earth.

Bulk said that the winds tend to blow perpendicular to the isobars in the equatorial regions and more or less parallel to the isobars in the polar regions. He said there are four major scales of wind systems: planetary, synoptic, mesoscale, and microscale. The planetary winds are measured in thousands of miles. These are the trade and monsoon wind patterns and have speeds of about $10-15 \mathrm{mph}$. The synoptic winds average about $10-25 \mathrm{mph}$, but can become quite violent over the oceans, getting up to speeds of approximately 60-80 $\mathrm{mph}$. These wind flows are also responsible for bringing the day to day weather changes, he said. The mesoscale wind systems range in size from 10-100 miles and are classified as land-sea, mountainvalley, and chinook winds. He said they are associated mainly with the passage of frontal systems and large scale storms such as hurricanes. Lastly, the microscale wind systems are measured from a few inches to a few tens of miles. The most common wind of this type is the tornado, which can have wind speeds from $200-300 \mathrm{mph}$. Also in this category are outflows from thunderstorms.

Bulk then examined the wind patterns of six Arizona towns: Phoenix, Flagstaff, Winslow, Prescott, Yuma, and Tucson. Phoenix has the lowest average wind speed, $6.3 \mathrm{mph}$, and Winslow the greatest, $8.9 \mathrm{mph}$. The highest peak wind gust occurred at Phoenix with the wind gusting to $86 \mathrm{mph}$ during a local July 1976 thunderstorm, while the lowest peak recorded was $46 \mathrm{mph}$ at Flagstaff when a cold front passed through the area in the late spring of 1975. The local topography of each site was highly influential in the average direction of the wind. The strongest wind gusts were recorded from local thunderstorms.

Bulk concluded by stating the Department of Energy did a study for wind power and the average wind speed needed for successful power is $15 \mathrm{mph}$. An average of $10 \mathrm{mph}$ covers $98.3 \%$ of the Arizona landscape and only $0.3 \%$ receives an average of $12.5 \mathrm{mph}$. Thus, there could only be limited use of wind power in Arizona.

After a question and answer period the meeting was adjourned at 8:15 pm. - Kim Brabander, Secy.

\section{Central Oklahoma}

The Central Oklahoma chapter met on the evening of 23 September at the University of Oklahoma. Approximately 100 members and guests attended. Chapter President Fred Carr opened the meeting

'Meeting reports received at headquarters before 12 November are included. Copy from chapter representatives should be typed doublespaced and submitted to the News Editor in duplicate. - News Ed. with general announcements.

Don Burgess, Chapter Vice-President, was the master of ceremonies for the evening's program of movies and slides taken during the spring 1981 severe storm season. The program was divided into three segments. The first included movies and slides taken by the National Severe Storms Laboratory's storm intercept team. Of particular interest were the movies taken of tornadoes on 17 May near Tecumseh, Okla., and on 22 May near the Oklahoma towns of Alphalfa, Cordell, and Binger. The second segment was a collection of slides taken by the University of Oklahoma intercept teams. The University of Oklahoma collection, presented by Howie Bluestein, included slides of nearly every severe storm that occurred in Oklahoma during April and May 1981. The third segment of the evening was open to anyone who cared to show samples of his or her storm phot ography. Several individuals took advantage of this opportunity to show their private collections of slides and movies taken last spring. - Kenneth W. Johnson, Secy.-Treas.

\section{Chicago}

The chapter held its second meeting of the year at the National Weather Service forecast facilities in Rosemont, Ill., on 3 November 1981. Dennis W. Trettel of Murray and Trettel, Inc., discussed a study that analyzed the potential use of horizontal axis wind turbines to generate electrical power.

Trettel began his talk by noting that Murray and Trettel was involved in the analysis of four sites characterized by different topographical features and meteorological conditions in order to obtain a cross-section of the various parameters that affect the motion of air currents. The study had four main objectives: to identify the synoptic pattern associated with particular winds, to find the conditions uniquely associated with certain winds, to estimate the potential of forecasting these winds, and to define any mesoscale features that might influence the air currents.

With these goals in mind, Trettel said a data analysis procedure was undertaken that employed wind data stratification, Booz-Allen synoptic pattern classification, $850 \mathrm{mb}$. wind data, and the surface wind patterns. Seven meters per second was used as a threshold for turbine operation, and this threshold was studied in light of the 850 $\mathrm{mb}$. winds, the pressure gradient within 150 nautical miles of the station, and the synoptic situation associated with days of potential generator use. This led to identification of particular ambient conditions and wind directions quite suitable for turbine operation at each site. However, Trettel noted that no uniform method for wind prediction could yet be developed, and further study was needed in this area. His concluding remarks suggested that even though the use of horizontal axis wind turbines is presently unpredictable, they can be a viable source of fuel and monetary savings. - Bill Phillips, Secy.

\section{El Paso-Las Cruces}

The El Paso-Las Cruces chapter met at Furr's Cafeteria in El Paso, Tex., on 22 September 1981. Doug Copp, Gary McWilliams, and Robert Schmidt were accepted into the chapter as new members. 
Chapter Secretary-Treasurer Stu Bowersox introduced the speaker of the evening, Robert Schmidt, a climatologist at the University of Texas-El Paso, who discussed the climate of the Chihuahua Desert. Since El Paso and much of southern New Mexico rests at the northern part of the desert, Schmidt's subject was of special interest, which is one possible reason for the excellent turnout.

Schmidt has studied the climate of the Chihuahua Desert since 1969. His studies have been of interest to both the United States and Mexico for agricultural reasons. Schmidt's studies show most of the rain that falls on the desert during the year falls between mid-June and mid-September and that $55 \%$ of the moisture comes from the Gulf of Mexico and the remaining 45\% from the Pacific Ocean. 1974 was a wet year for the desert. Through the use of satellite pictures Schmidt showed how much of the rain that fell in 1974 came from Hurricane Fifi and inverted troughs from the Gulf of Mexico. He theorized that the possible reason why little is known about Pacific storms off the coast of Mexico is the lack of ships passing through the area. Thus, little information on such storms is noted. Schmidt is continuing his studies of the Chihuahua Desert climate.

The chapter met again on 27 October 1981. Chapter SecretaryTreasurer Stu Bowersox said he had been asked to have the chapter judge at the 1982 El Paso School District's Science Fair. Chapter President Steve Cohn also said the Southern New Mexico School District would like to have the chapter judge at their science fair. The chapter members accepted both judging assignments and decided to accept volunteers later.
Bowersox then introduced the evening's speaker, Willis Webb, who works in the Physics Department at the University of Texas-El Paso. He talked on the Meteorological Rocket Network (MRN) archives to be dedicated at the University on 2 February 1982. Webb said the MRN data show the importance of the upper air and the abundance of synoptic information MRN has supplied. Webb stated that the archives would soon become the basis of many dissertations when the environmental sciences doctorate program begins at the University. He said that the ceremony, to be held at the student union building, needed support. He also needs more examples of ozone and temperature soundings. Webb said U.S. Congressman Richard White will be one of the principal speakers at the dedication. He concluded by saying the MRN data will be the first significant scientific archives ever assembled at the University of Texas-El Paso and that the local chapter should invite friends from all over the country as well as El Paso for the occasion - Stuart Bowersox, Secy.-Treas.

\section{Houston}

"The Atmospheres of Other Planets" was the subject of the 17 October 1981 meeting of the Houston chapter, held at the Institute for Storm Research. Twenty-one people attended.

According to David Pitts, of the National Aeronautics and Space Administration's Earth Observation Division, recent exploration in

\section{CONFERENCE ON CLIMATE AND ENERGY: CLIMATOLOGICAL ASPECTS AND INDUSTRIAL OPERATIONS

\section{May 8-12, 1978 Asheville, N.C.}

The Conference on Climate and Energy: Climatological Aspects and Industrial Operations, sponsored by the American Meteorological Society, was held 8-12 May 1978 in Asheville, N.C. Since applied climatology is a primary activity, tool, or concern of every working industrial meteorologist, it is most appropriate that these two subdisciplines of meteorology are presented side-by-side in the 41 papers of this preprint volume.

The papers are arranged under the following topics:

Energy Consumption/Conservation $\bullet$ Modeling $\bullet$ Solar and Wind
Energy $\bullet$ Effects of Power Production on Climate $\bullet$ Effects of Energy
Usage on Climate $\bullet$ Industrial Meteorology and Energy $\bullet$ Forensic
Meteorology $\bullet$ Meteorology and the Offshore Industry $\bullet$ Effects of
Weather Extremes

194 pages

Send order and remittance to:
$\$ 15$ AMS Members

$\$ 20$ Nonmembers

(plus $\$ 2.00$ postage/handling)

\section{AMERIGAN METEOROLOGIGAL SOGIETY 45 BEACON ST., BOSTON, MASS. 02108}


space has provided startling information about the atmospheres of other planets, but much is still unknown.

Pitts described many of the latest theories concerning each of the planetary atmospheres, and described many of the unmanned exploratory space flight missions. The presentation included color slides of Jupiter, provided by the Lunar Planetary Institute, and a brief explanation of a tephigram for Mars (developed by Pitts). James J. Schnebelt, Secy.

\section{Puget Sound}

On 7 October 1981, the Puget Sound chapter had its first meeting of the season. The guest speaker, Don McGrew of the Boeing Wind Energy Program, talked about the Boeing wind energy efforts in the Northwest. The Boeing Company has constructed three huge windmills on Goodnoe Hills near Goldendale, Wash., a town about 100 miles east-northeast of Portland, Ore. The site was chosen because it lies on a ridge just east of the Columbia River Gorge, a natural channel through the Cascade Mountains that causes air to funnel and therefore speed up whenever there is a pressure difference between the east and west sides of the mountains. Although not as windy as some high mountain ridges, its easy accessibility by road and closeness to power lines made it the prime choice for the experiment.

These windmills were constructed with a $300 \mathrm{ft}$ diameter blade. A computerized base pivots around so that the blades are always facing into the wind. Each of the windmills is able to deliver a maximum of 2.5 MW of power when the wind is sustained at $28 \mathrm{mph}$. The blades are feathered automatically during high winds to prevent damage. The machines have been designed to have a life of 30 years. It is hoped that eventually a number of windmill "farms" can be developed that will provide supplementary electrical power relatively inexpensively, compared to fossil fuels or nuclear power. It has been determined that they can be spaced as close as 10 diameters away without interfering with one another. Even larger windmills are on the designers' board.

At the end of the talk, Chapter President Ron Lindsay announced that the next meeting would be held 2 December 1981. - William D. Burton, Secy.-Treas.

\section{Twin Cities}

At the October meeting, the Twin Cities chapter passed a motion made by Dean Braatz to offer sponsorship of AMS's 5th National Conference on Hydrometeorology, which the AMS STAC Committee on Hydrology is planning for August or September 1983. Braatz, head of the River Forecast Center, will continue to provide liaison with the national committee.

The program speaker, Calvin Alexander of the University of Minnesota Department of Geology and Geophysics, gave a fascinating address on the karst geology of southeastern Minnesota, with particular emphasis on the resulting water pollution problems there. Karst geology is bedrock characterized by natural cracks ("joints") occurring about every meter; some individual cracks are as long as a mile. In some cases, the cracks have widened to a mile and a half and opened in depth to the underlying St. Peter sandstone layer.

The result of the geology has been the formation of sink holes, caves, underground rivers, disappearing streams, etc.; and the surface water, in some areas, will descend to the underground channels in less than 4 hours. Precipitation can act quickly to carry surface pollutants through the ground water system to the Mississippi River. Unfortunately, the sink-hole areas are also favorite dumping areas, usage which acts to funnel pollutants into the ground water transport to the river basin.

Karst terrain and its consequences for pollution transport are only now becoming known. Fifty percent of the United States has karsttype bedrock underlying it and about $20 \%$ of the soil layer has karst immediately beneath. - Doug Kohl, Secy.

\section{University of Rhode Island (Student)}

The University of Rhode Island Chapter has elected new officers for the 1981-82 academic year. They are: President, James B. Wilson; Vice-President, Paul Dellagatto; and Secretary-Treasurer, Patricia Brennan.

Chapter activities include competing in the National Weather Forecasting Contest sponsored by the University of MissouriColumbia; interning at the weather center at WLNE, Providence, R.I., and serving as guest lecturers for local organizations. The chapter is looking forward to a successful and educational year. James B. Wilson, Pres.

\section{Utah}

The Utah chapter held its first meeting of the 1981-82 season on 24 September at the University of Utah Fletcher Building. The meeting opened with short overviews from the new chapter officers on their plans and programs for the current year, followed by a financial report from the Secretary-Treasurer.

The speaker for the evening was Denis Siu, the National Weather Service fire-weather focal point for Utah. Siu discussed many aspects of his job and his relationship with the agencies he supports.

His primary job as a fire-weather focal point is to provide meteorological support to fire suppression agencies. In Utah, this support is provided to the U.S. Forest Service (USFS), the Bureau of Land Management (BLM), the State of Utah, the National Park Service, and the Bureau of Indian Affairs. During the fire season (1 June-31 October), this support is provided from a special Fire-Weather Forecast Office at the Utah Interagency Fire Center in Salt Lake City. The Center is manned by the USFS, BLM, State of Utah, and the NWS (represented by Siu). Siu finds that locating the main fire suppression agencies and his office together greatly facilitates planning and cooperation in combating wildfires. For the remainder of the year, he provides fire-weather support from the Weather Service Forecast Office in Salt Lake City.

The fire-weather office is equipped with National Facsimile Circuit (NAFAX), Radar Facsimile Circuit (RAFAX), UNIFAX, Service "A", Service "C", a transmit / receive fire-weather teletypewriter (with 19 drops), and an AFFIRMS computer. There are also 29 fire-weather observing sites which at 2:00 pm each day transmit an observation to the fire-weather office. Denis provides several indepth forecast packages to his users each day. The main forecast parameters are wind, temperature, relative humidity, and thunderstorms. He also provides the weather input into the AFFIRMS computer. This computer takes the weather input along with several other inputs and turns out indexes of burning, which are used by the fire suppression agencies to evaluate the fire threat and deploy their personnel accordingly. Siu also provides forecasts for every wildfire that breaks out in Utah. If the fire is big enough, he joins the fire-fighting team at the wildfire and provides on-site support, using the NWS fire-weather mobile unit (a 1972 truck and camper), which is equipped with a mini-fax, a portable weather station, a radio, and a theodolite. Siu feels on-site support is the most challenging and rewarding part of his job. He can expect to spend four to seven days 
at a wildfire about four to five times each year.

Siu noted that during August, Utah had 413 fires, which destroyed 23000 acres; and for the 1981 fire season so far, over 200000 acres have been burned. Most of the fires were lightning-caused, with human-caused fires coming in a close second.

Siu then presented two slide shows. The first showed the various fire-fighting equipment and its use. The second showed some very dramatic slides of the infamous Challis National Forest Fire in Idaho in 1979, which raged for 22 days and covered 102 square miles. The fire was finally controlled with the help of heavy rain. The presentation came to a close with Siu fielding several questions from the audience. - Ed Carle, Secy.-Treas.

\section{West Central Florida}

Fifty-four members were present at the 26 March 1981 chapter meeting at WTSP-TV Channel 10 (ABC). At 7:30 pm, chapter members were ushered into the main studio, greeted, and lectured to by Staff Weathercaster and Meteorologist Jim Menard about the station's new computer system.

Chief Weathercaster and Meteorologist Dick Fletcher briefly discussed his trip to the "Severe Storms Workshop" held at the National Weather Service Conference in Kansas City, Mo. Another brief discussion was given about WTSP-TV Channel 10's recent complete studio and station renovation.

Three groups were formed; their meteorologist guides were Dick Fletcher, Jim Menard, and Wally Kinnan. Members were first led to the Production Control Room, where they were shown audio and video effects including: "Chroma-key," a method used to artificially project weather graphics next to the meteorologist while on the air; "Video Switching," a device which allows station personnel to control the many sources of video within the station, such as radar, computer graphic camera, network feed, etc.; the Audio Board, which switches and mixes various sources of audio from within the station; and the character generator, a form of electronic typewriter that allows the printing of letters and numbers on the TV screen.

From this section members were escorted to the Engineering Department, where they saw a variety of equipment, such as video tape machines, camera control units, microwave transmitters and receivers, etc., all of the very latest and most modern design.

The News Department was the next place members visited. There, they were shown ENG (electronic news gathering) equipment, including video tape editing and live remote transmitters and receivers that allow the station to air live news reports from any location within its viewing area. Next they saw the many news wire machines, including those of AP, UPI, and many other news sources. Sources of weather data include Florida Weather Wire Teletypewriter, National Facsimile Circuit (NAFAX), GOES, Color Radar, and Weather Eye (a computer especially programed by Jim Menard, used to display computer graphics and analyze various forms of weather data on the air).

After this most educational tour through WTSP-TV Channel 10, the three groups were led back to the main studio, where a question and answer session was held. The meeting adjourned 9:00 pm. Albert C. Wappler, Corresponding Secy.

\section{Western New York}

The second chapter meeting of the season was held on 29 October 1981 at Niagara University. The guest speaker was Bill Boeck, a professor at the University, who gave an enlightening presentation on thunderstorms and atmospheric electricity. A film was shown, after which the 25 members present took part in a lively question and

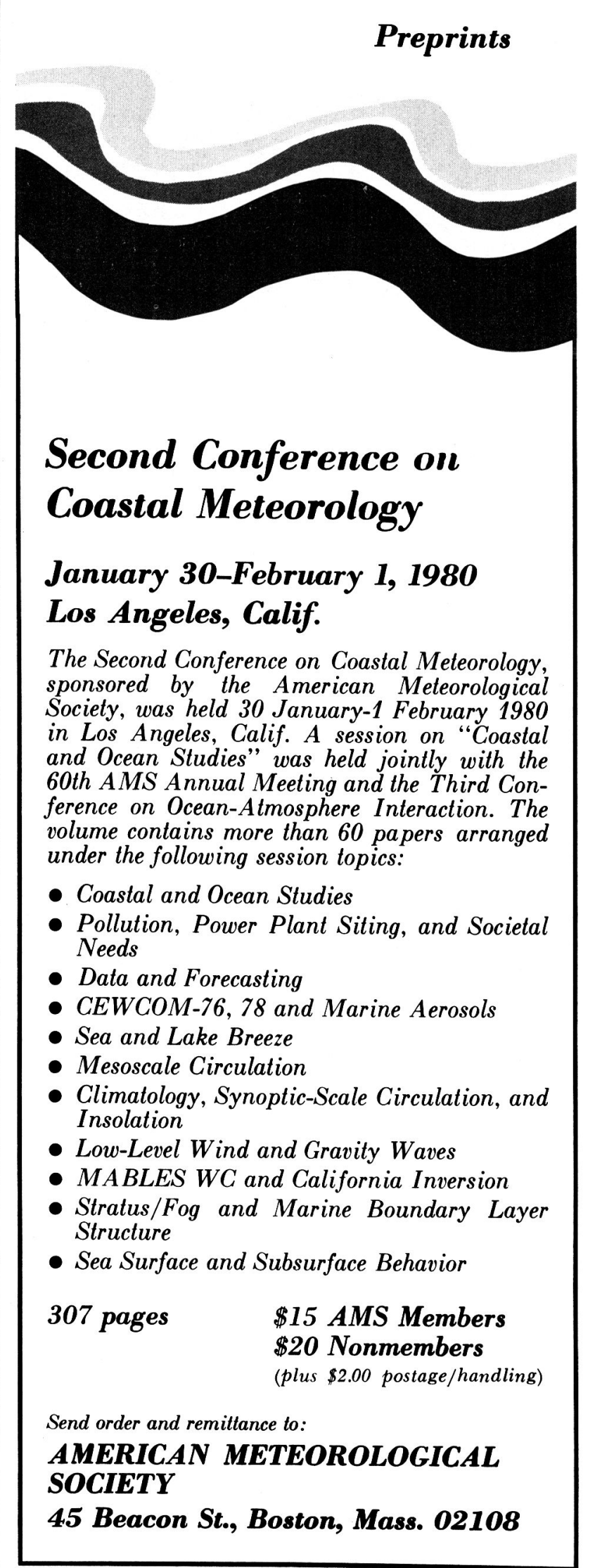


answer session, which included discussions of ball lightning, heat lightning, and ground-to-cloud strokes. Of special interest during the presentation were some "still" photos capturing the many strokes in each bolt (usually not visible to the naked eye) and ground-to-cloud lightning. Boeck presented many theories about the electrical makeup of the thunderstorm but concluded that people have yet to understand fully the complexities of the storm.

Secretary-Treasurer Steve McLaughlin then followed with an update on chapter activities: membership status, future meetings, and, of course, the expanding "snow spotters" network, which is gearing up for another western New York winter. WGR-TV meteorologist Eric Warren, who was at the meeting, expressed interest in aiding the chapter in presenting the results to the general public. Additional AMS applications were distributed and refreshments were then served. The official membership of the chapter has now reached 30. - Steve McLaughlin, Secy.-Treas.

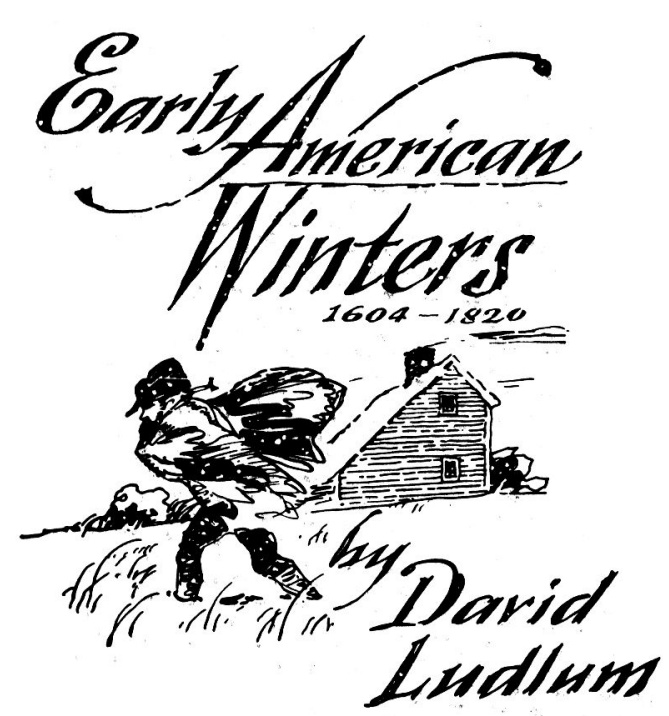

A two-volume

chronicle and chronology

of the important

meteorological events of early

winters in the Northeast, the

Old South, and the Old

Northwest, from Samuel

Champlain's first season on the

Atlantic seaboard (1604) to the

"first" blizzard (March 1870).

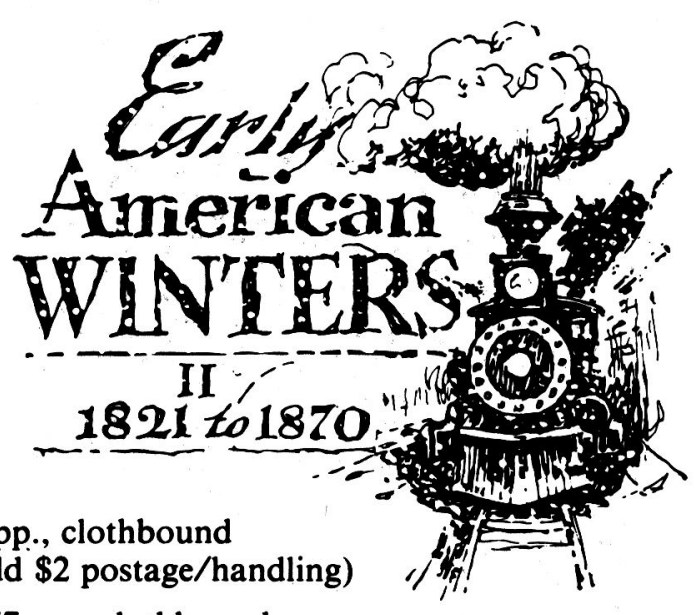

Early American Winters 1604-1820, (1966), 285 pp., clothbound AMS Members $\$ 7.00$ Nonmembers $\$ 12.00$ (add $\$ 2$ postage/handling)

Early American Winters II 1821-1870, (1968), 257 pp., clothbound AMS Members $\$ 7.00$ Nonmembers $\$ 12.00$ (add $\$ 2$ postage/handling)

Set of Both Volumes: Members $\$ 12$ Nonmembers $\$ 22$ (add $\$ 3$ postage/handling) Send orders to:

AMERICAN METEOROLOGICAL SOCIETY, 45 Beacon St., Boston, Mass. 02108 